Article

\title{
Effects of Ca/Si Ratio, Aluminum and Magnesium on the Carbonation Behavior of Calcium Silicate Hydrate
}

\author{
Jing Li $\odot$, Qijun Yu, Haoliang Huang and Suhong Yin * \\ School of Materials Science and Engineering, South China University of Technology, Guangzhou 510640, China; \\ Jing-Li@hotmail.com (J.L.); concyuq@scut.edu.cn (Q.Y.); h.l.huang@msn.com (H.H.) \\ * Correspondence: imshyin@scut.edu.cn; Tel.: +86-20-8711-4137
}

Received: 11 March 2019; Accepted: 15 April 2019; Published: 18 April 2019

check for

updates

\begin{abstract}
The effects of $\mathrm{Ca} / \mathrm{Si}$ ratio, aluminum and magnesium on the carbonation behavior of calcium silicate hydrate (C-S-H) were investigated by using X-ray powder diffraction (XRD), nuclear magnetic resonance (NMR) and thermogravimetric analyzer (TGA). The results showed that the $\mathrm{Ca} / \mathrm{Si}$ ratio, $\mathrm{Al} / \mathrm{Si}$ ratio and $\mathrm{Mg} / \mathrm{Si}$ ratio had a significant influence on the structure, carbonation products and carbonation resistance of C-(M)-(A)-S-H. The mean chain length of silicate chains in C-S-H increased as the $\mathrm{Ca} / \mathrm{Si}$ ratio decreased. Aluminum uptake in C-S-H increased the content of bridging silicate tetrahedron $\left(\mathrm{Q}^{2}\right)$. A cross-linked structure $\left(\mathrm{Q}^{3}\right)$ appeared when magnesium uptake in C-S-H. The carbonation product of $\mathrm{C}-\mathrm{S}-\mathrm{H}$ was vaterite if the $\mathrm{Ca} / \mathrm{Si}$ ratio was lower than 0.87 . The carbonation products of $\mathrm{C}-\mathrm{S}-\mathrm{H}$ were vaterite and calcite if the $\mathrm{Ca} / \mathrm{Si}$ ratio was higher than 1.02. C-M-S-H had more polymerized units, stronger bond strength and better carbonation resistance than C-S-H.
\end{abstract}

Keywords: C-S-H; Ca/Si ratio; $\mathrm{Al} / \mathrm{Si}$ ratio; $\mathrm{Mg} / \mathrm{Si}$ ratio; carbonation behavior

\section{Introduction}

Calcium silicate hydrate (C-S-H) is the main reaction product of alkali-activated slag (AAS) [1]. The carbonation of C-S-H is a process of decalcification when $\mathrm{CO}_{2}$ reacts with calcareous phases, resulting in the decomposition of C-S-H, the formation of calcium carbonate with different crystalline forms (i.e., calcite, aragonite and vaterite) and silica gel, and damage to AAS [2-4]. Therefore, the carbonation resistance of C-S-H is one of the key factors governing the durability of AAS [5,6].

Many researchers studied the carbonation behavior of C-S-H to improve the carbonation resistance of cementitious materials. According to literatures, the carbonation behavior of C-S-H mainly depends on its structure, which is affected by the Ca/Si ratio, uptake of aluminum and magnesium in C-S-H [7-10].

$\mathrm{C}-\mathrm{S}-\mathrm{H}$ is a kind of amorphous phase with layer structure [11]. An increment of $\mathrm{Ca} / \mathrm{Si}$ ratio leads to a reduction of the silicate chain length and of the interlayer spacing [12,13]. In the AAS system, aluminum is most likely incorporated in the C-S-H structure due to the high content of aluminum [8,14]. Many structure models of C-S-H have been proposed [15-17]. There is a model named the "Cross-linked Substituted Tobermorite Model" (CSTM) that can explain the structure evolution when aluminum uptake in C-S-H [18]. The positions of aluminum in C-S-H have been widely investigated by mean of nuclear magnetic resonance. There are five kinds of positions for aluminum uptake in C-S-H, including two kinds of $\mathrm{Al}$ (IV) [19,20], a kind of $\mathrm{Al}(\mathrm{V})[21,22]$ and two kinds of $\mathrm{Al}$ (VI) [23]. $\mathrm{Al}(\mathrm{IV})$ represents the aluminum enters the pairing $\left(\mathrm{Q}^{2}\right)$ or bridging tetrahedra $\left(\mathrm{Q}^{3}\right)$. If $\mathrm{Al}$ (IV) occurs in $\mathrm{Q}^{3}$ sites (bridging position), cross-linked structure will appear. $\mathrm{Al}(\mathrm{V})$ represents the aluminum enters the position of interlayer. $\mathrm{Al}(\mathrm{VI}-1)$ represents the aluminum that enters the position of interlayer or in the C-S-H structure by replacing calcium [24]. Al (VI-2) stands for the third aluminate hydrate (TAH) which is a precipitate with C-S-H [25]. In a recent study, reference [26] suggested that the aluminum mainly taken up as $\mathrm{Al}(\mathrm{VI})$ in $\mathrm{TAH}$ when the $\mathrm{Ca} / \mathrm{Si}$ ratio of $\mathrm{C}-\mathrm{S}-\mathrm{H}$ was high, otherwise, 
aluminum mainly enters $\mathrm{Al}$ (IV) [26]. As for magnesium, early reports believed that magnesium can enter the C-S-H structure by occupying the position of calcium [25,27-29]. However, more recently, Bernard et al. studied the effect of magnesium on C-S-H [10,30,31]. They suggested that magnesium will react with silicate ions to form magnesium silicate hydration (M-S-H) [10].

$\mathrm{The} \mathrm{Ca} / \mathrm{Si}$ ratio, aluminum and magnesium have effects not only on the structure of C-S-H but also on the carbonation resistance of C-S-H [7,12-14]. To figure out the effect of the Ca/Si ratio on the carbonation behavior of C-S-H without the interference of other phases, a few researchers studied the carbonation behavior of pure C-S-H that achieved by mean of chemosynthesis [5,32-35]. Black et al. studied the carbonation of synthesized C-S-H (initial Ca/Si ratio: 0.4-1.5), and indicated that C-S-H with low $\mathrm{Ca} / \mathrm{Si}$ ratio had a better carbonation resistance [36,37]. However, Sevelsted et al. believed that the decomposition rate of C-S-H increased with the decrease of $\mathrm{Ca} / \mathrm{Si}$ ratio [5], which was not consistent with the aforementioned findings. Therefore, further study on the effect of $\mathrm{Ca} / \mathrm{Si}$ on carbonation of $\mathrm{CSH}$ is necessary. Moreover, the changes in carbonation behavior of C-S- $\mathrm{H}$ when $\mathrm{Al}$ and $\mathrm{Mg}$ are taken in by C-S-H were not clear.

In this study, C-(M)-(A)-S-H with different $\mathrm{Ca} / \mathrm{Si}$ ratio, $\mathrm{Al} / \mathrm{Si}$ ratio and $\mathrm{Mg} / \mathrm{Si}$ ratio were synthesized by means of the chemical precipitation method. The effects of the $\mathrm{Ca} / \mathrm{Si}$ ratio, aluminum and magnesium on the structure of C-S-H were investigated by means of X-ray powder diffraction (XRD) and ${ }^{29} \mathrm{Si}$ nuclear magnetic resonance (NMR). The carbonation products of C-S-H were analyzed by using X-ray powder diffraction. The content of carbonation products of C-S-H were investigated by means of thermogravimetric analyzer (TGA), XRD and the Rietveld method. In this way, insights into the effects of $\mathrm{Ca} / \mathrm{Si}$ ratio, aluminum and magnesium on the carbonation behavior of $\mathrm{C}-\mathrm{S}-\mathrm{H}$ were provided.

\section{Experiments}

\subsection{Synthesis of C-(M)-(A)-S-H with Different Ca/Si Ratio, Al/Si Ratio and Mg/Si Ratio}

Preparation of C-S-H with different $\mathrm{Ca} / \mathrm{Si}$ ratio by using chemical precipitation method. The chemical reagents used in the following work were the analytical grade. The C-S-H with initial $\mathrm{Ca} / \mathrm{Si}$ ratio from 0.67 to 1.6 were prepared by using the chemical precipitation method $[13,15]$. Calcium nitrate solution $\left(\mathrm{Ca}\left(\mathrm{NO}_{3}\right)_{2} \cdot 4 \mathrm{H}_{2} \mathrm{O}, 150 \mathrm{~mL}\right)$ with molarity of $0.067 \mathrm{M}, 0.10 \mathrm{M}, 0.12 \mathrm{M}, 0.14 \mathrm{M}$ and $0.16 \mathrm{M}$ were added drop by drop into sodium silicate solution with molarity of $0.1 \mathrm{M}\left(\mathrm{Na}_{2} \mathrm{SiO}_{3} \cdot 5 \mathrm{H}_{2} \mathrm{O}\right.$, $150 \mathrm{~mL})$, respectively. Sodium hydroxide particles $(\mathrm{NaOH})$ were added into sodium silicate solution to keep the $\mathrm{pH}$ value of the mixed solution over 13. Ultrapure water was boiled for $10 \mathrm{~min}$ to remove the dissolved carbon dioxide $\left(\mathrm{CO}_{2}\right)$. The mixed solution was stirred constantly during the whole process ( 1 day). The entire synthesizing process was under a $\mathrm{N}_{2}$ atmosphere at a room temperature. A white gel was precipitated immediately as the calcium nitrate solution drops to the sodium silicate solution. Separation of gel from the liquid was conducted by using a centrifugal machine (DL-5-B, Anke, Shanghai, China). After that, the gel was washed twice with ultrapure and decarbonized water to remove the sodium and nitrate ions. Finally, the obtained gel was dried at $60{ }^{\circ} \mathrm{C}$ for 7 days in a vacuum drying chamber (DZF-6050, Yiheng, Shanghai, China).

Preparation of C-A-S-H with different $\mathrm{Al} / \mathrm{Si}$ ratio by using chemical precipitation method. The procedures to synthesize $\mathrm{C}-\mathrm{A}-\mathrm{S}-\mathrm{H}$ with different $\mathrm{Al} / \mathrm{Si}$ ratio were the same as those to synthesize C-S-H. A $0.10 \mathrm{M}$ sodium silicate solution $\left(\mathrm{Na}_{2} \mathrm{SiO}_{3} \cdot 5 \mathrm{H}_{2} \mathrm{O}, 100 \mathrm{~mL}\right)$ was used as the source of silicon, a $0.12 \mathrm{M}$ calcium nitrate solution $\left(\mathrm{Ca}\left(\mathrm{NO}_{3}\right)_{2} \cdot 4 \mathrm{H}_{2} \mathrm{O}, 100 \mathrm{~mL}\right)$ was used as the source of calcium, and $0.00125 \mathrm{M}, 0.0025 \mathrm{M}, 0.005 \mathrm{M}, 0.01 \mathrm{M}$, and $0.02 \mathrm{M}$ aluminum nitrate solution $\left(\mathrm{Al}\left(\mathrm{NO}_{3}\right)_{3} \cdot 9 \mathrm{H}_{2} \mathrm{O}, 100 \mathrm{~mL}\right)$ were used as the source of silicon aluminum.

Preparation of C-M-S-H with different $\mathrm{Mg} / \mathrm{Si}$ ratio by using chemical precipitation method. The procedures to synthesize C-M-S- $\mathrm{H}$ with a different $\mathrm{Mg} / \mathrm{Si}$ ratio were the same as those to synthesize C-S-H. A $0.10 \mathrm{M}$ sodium silicate solution $\left(\mathrm{Na}_{2} \mathrm{SiO}_{3} \cdot 5 \mathrm{H}_{2} \mathrm{O}, 100 \mathrm{~mL}\right)$ was used as the source of silicon, a $0.12 \mathrm{M}$ calcium nitrate solution $\left(\mathrm{Ca}\left(\mathrm{NO}_{3}\right)_{2} \cdot 4 \mathrm{H}_{2} \mathrm{O}, 100 \mathrm{~mL}\right)$ was used as the source of calcium, and 
$0.00125 \mathrm{M}, 0.0025 \mathrm{M}, 0.005 \mathrm{M}, 0.01 \mathrm{M}$, and $0.02 \mathrm{M}$ magnesium nitrate solution $\left(\mathrm{Mg}\left(\mathrm{NO}_{3}\right)_{2} \cdot 6 \mathrm{H}_{2} \mathrm{O}\right.$, $100 \mathrm{~mL}$ ) were used as the source of silicon magnesium.

The detailed information of the samples are listed in Table 1. The initial $\mathrm{Ca} / \mathrm{Si}$ ratio, $\mathrm{Al} / \mathrm{Si}$ ratio and $\mathrm{Mg} / \mathrm{Si}$ ratio of C-(M)-(A)-S-H ranged from 0.67 to $1.6,0.0125$ to 0.2 , and 0.0125 to 0.2 , respectively. But the real Ca/Si ratio of C-S-H ranged from 0.64 to 1.25 , which were measured by mean of X-ray fluorescence (XRF, PANalytical, Almelo, Overijssel, The Netherlands).

Table 1. The detailed information of synthesized samples.

\begin{tabular}{|c|c|c|c|c|c|c|c|}
\hline Samples ${ }^{a}$ & $\begin{array}{c}\text { Initial } \mathrm{Ca} / \mathrm{Si} \\
\text { Ratio }\end{array}$ & $\begin{array}{c}\text { Initial Al/Si } \\
\text { Ratio }\end{array}$ & $\begin{array}{c}\text { Initial } \mathrm{Mg} / \mathrm{Si} \\
\text { Ratio }\end{array}$ & $\begin{array}{c}\text { Real Ca/Si } \\
\text { Ratio }\end{array}$ & $\begin{array}{c}\text { Real Al/Si } \\
\text { Ratio }\end{array}$ & $\begin{array}{c}\text { Real Mg/Si } \\
\text { Ratio }\end{array}$ & MQA $^{b}$ \\
\hline CSH_0.64 & 0.67 & 0 & 0 & 0.64 & 0 & 0 & TGA $^{c}$ \\
\hline CSH_0.87 & 1.0 & 0 & 0 & 0.87 & 0 & 0 & TGA \\
\hline CSH_1.02 & 1.2 & 0 & 0 & 1.02 & 0 & 0 & TGA \\
\hline CSH_1.14 & 1.4 & 0 & 0 & 1.14 & 0 & 0 & TGA \\
\hline CSH_1.25 & 1.6 & 0 & 0 & 1.25 & 0 & 0 & TGA \\
\hline CASH__0.02 & 1.2 & 0.0125 & 0 & 0.77 & 0.018 & 0 & $X_{R D}{ }^{d}$ \\
\hline CASH_0.03 & 1.2 & 0.025 & 0 & 0.80 & 0.034 & 0 & XRD \\
\hline CASH_0.05 & 1.2 & 0.05 & 0 & 0.77 & 0.054 & 0 & XRD \\
\hline CASH_0.08 & 1.2 & 0.1 & 0 & 0.83 & 0.081 & 0 & XRD \\
\hline CASH_0.14 & 1.2 & 0.2 & 0 & 0.86 & 0.14 & 0 & XRD \\
\hline CMSH_0.01 & 1.2 & 0 & 0.0125 & 0.92 & 0 & 0.013 & XRD \\
\hline CMSH_0.02 & 1.2 & 0 & 0.025 & 0.96 & 0 & 0.022 & XRD \\
\hline CMSH_0.05 & 1.2 & 0 & 0.05 & 0.95 & 0 & 0.052 & XRD \\
\hline CMSH_0.09 & 1.2 & 0 & 0.1 & 0.87 & 0 & 0.090 & XRD \\
\hline CMSH_0.16 & 1.2 & 0 & 0.2 & 0.96 & 0 & 0.16 & XRD \\
\hline
\end{tabular}

a The initial $\mathrm{Ca} / \mathrm{Si}$ ratio, initial $\mathrm{Al} / \mathrm{Si}$ ratio and initial $\mathrm{Mg} / \mathrm{Si}$ ratio of $\mathrm{C}-(\mathrm{M})-(\mathrm{A})-\mathrm{S}-\mathrm{H}$ were obtained by calculating. The real $\mathrm{Ca} / \mathrm{Si}$ ratio, real $\mathrm{Al} / \mathrm{Si}$ ratio and real $\mathrm{Mg} / \mathrm{Si}$ ratio of $\mathrm{C}-(\mathrm{M})-(\mathrm{A})-\mathrm{S}-\mathrm{H}$ were measured by using X-ray fluorescence (XRF). ${ }^{b}$ Method for quantitative analysis of the $\mathrm{CaCO}_{3}$ content after carbonation experiment. ${ }^{\mathrm{c}}$ TGA is short for thermogravimetric analyzer. ${ }^{\mathrm{d}} \mathrm{XRD}$ is short for X-ray diffraction.

\subsection{Experiment of Carbonation}

All the samples were ground into powder and passed through a sieve with $75 \mu \mathrm{m}$ before carbonation. Powders of the prepared C-S-H were exposed to atmospheric $\mathrm{CO}_{2}$ for 1 day, 7 days, and 28 days with temperature of $20 \pm 2{ }^{\circ} \mathrm{C}$ and humidity of $65 \% \pm 5 \%$.

\subsection{Polymerization of Silicon Chain}

The data of ${ }^{29} \mathrm{Si}$ nuclear magnetic resonance (NMR) were recorded on an AVANCE III 400 NMR spectrometer (Bruker, Fällanden, Zürich, Switzerland). The mean silicate chain length (CL) of C-S-H was calculated as follows [5]:

$$
\overline{\mathrm{CL}}=2\left(\mathrm{Q}^{1}+\mathrm{Q}_{\mathrm{b}}{ }^{2}+\mathrm{Q}_{\mathrm{u}}{ }^{2}+\mathrm{Q}_{\mathrm{P}}{ }^{2}\right) / \mathrm{Q}^{1}
$$

where $\mathrm{Qb}_{\mathrm{b}}{ }^{2}$ is the bridging tetrahedron with calcium; $\mathrm{Qu}^{2}$ is the bridging tetrahedron with an $\mathrm{H}^{+} ; \mathrm{Q}_{\mathrm{p}}{ }^{2}$ is the pairing tetrahedron.

\subsection{The Carbonation Products}

The mineralogical identification of C-(M)-(A)-S-H before and after carbonation was analyzed by XRD (PANalytical, Almelo, Overijssel, The Netherlands). XRD patterns were recorded on a Panlytical X'Pert PRO X-ray diffraction with $\mathrm{Cu}-\mathrm{K} \alpha$ radiation. The $\mathrm{X}$-ray tube was operated at $40 \mathrm{kV}$ and $40 \mathrm{~mA}$. Values for qualitative analysis were recorded at $2 \theta$ intervals from $5^{\circ}$ to $70^{\circ}$ with a step size of $0.033^{\circ}$ for $10 \mathrm{~s}$.

\subsection{The Content of Carbonation Products}

\subsubsection{The Content of Carbonation Products for C-S-H}

The quantitative analysis of carbonation products of C-S-H with different $\mathrm{Ca} / \mathrm{Si}$ ratio was carried out by using a thermogravimetric analyzer (TGA, STA 182 449C, Netzsch, Selb, Bavaria, Germany) 
with a heating rate of $10{ }^{\circ} \mathrm{C}$ per minute in $\mathrm{N}_{2}$ atmosphere from room temperature to $1000{ }^{\circ} \mathrm{C}$. Samples were characterized by mean of TGA with and without carbonation. The amounts of $\mathrm{CaCO}_{3}$ is determined directly via the weight loss of samples at the temperature of $500-900{ }^{\circ} \mathrm{C}$ instead of tangent method [38,39]. The content of carbonation products (CCP) was calculated as follows:

$$
\mathrm{CCP}=\mathrm{WL}_{2} / \mathrm{T}_{2} \times 100 \%-\mathrm{WL}_{1} / \mathrm{T}_{1} \times 100 \%
$$

where, $\mathrm{CCP}$ is content of carbonation products; $\mathrm{WL}_{1}$ is the weight loss of a sample in decomposition peak of $\mathrm{CaCO}_{3}$ before carbonation; $\mathrm{T}_{1}$ is the total weight of corresponding sample before carbonation in TGA test; $\mathrm{WL}_{2}$ is the weight loss of a sample in decomposition peak of $\mathrm{CaCO}_{3}$ after carbonation; $\mathrm{T}_{2}$ is the total weight of corresponding sample after carbonation in TGA test.

\subsubsection{The Content of Carbonation Products for C-A-S-H and C-M-S-H}

The quantification of carbonation products of C-A-S-H and C-M-S-H was studied by means of XRD and Rietveld method. Values for quantitative analysis were recorded at $2 \theta$ intervals from $10^{\circ}$ to $70^{\circ}$ with a step size of $0.017^{\circ}$ for $20 \mathrm{~s}$ The internal standard substance was brucite with content of $15 \mathrm{wt}$. $\%$.

\section{Results and Discussion}

\subsection{The Effects of Ca/Si, Al/Si and Mg/Si Ratios on the Structure of C-(M)-(A)-S-H}

The real $\mathrm{Ca} / \mathrm{Si}$ ratio, $\mathrm{Al} / \mathrm{Si}$ ratio and $\mathrm{Mg} / \mathrm{Si}$ ratio of synthesized $\mathrm{C}-(\mathrm{M})-(\mathrm{A})-\mathrm{S}-\mathrm{H}$ were presented in Table 1 after being measured using X-ray fluorescence. The real $\mathrm{Ca} / \mathrm{Si}$ ratio, $\mathrm{Al} / \mathrm{Si}$ ratio and $\mathrm{Mg} / \mathrm{Si}$ ratio of synthesized C-(M)-(A)-S-H were range from 0.64 to 1.25 , from 0 to 0.14 , and from 0 to 0.16 , respectively. It was clear that the real $\mathrm{Ca} / \mathrm{Si}$ ratio of synthesized $\mathrm{C}-\mathrm{S}-\mathrm{H}$ was smaller than the initial $\mathrm{Ca} / \mathrm{Si}$ ratio that applied for synthesis, especially for the samples with high initial $\mathrm{Ca} / \mathrm{Si}$ ratio $(\mathrm{Ca} / \mathrm{Si}$ $>1$ ). The XRD patterns of synthesized C-(M)-(A)-S-H with different $\mathrm{Ca} / \mathrm{Si}$ ratios, $\mathrm{Al} / \mathrm{Si}$ ratios and $\mathrm{Mg} / \mathrm{Si}$ ratios are shown in Figure 1. The characteristic peaks of C-S-H (d: 3.07, 2.80, 1.83; PDF\#34-0002) appeared in the all diffraction patterns, indicating the C-S-H could be obtained by means of the chemical precipitation method.

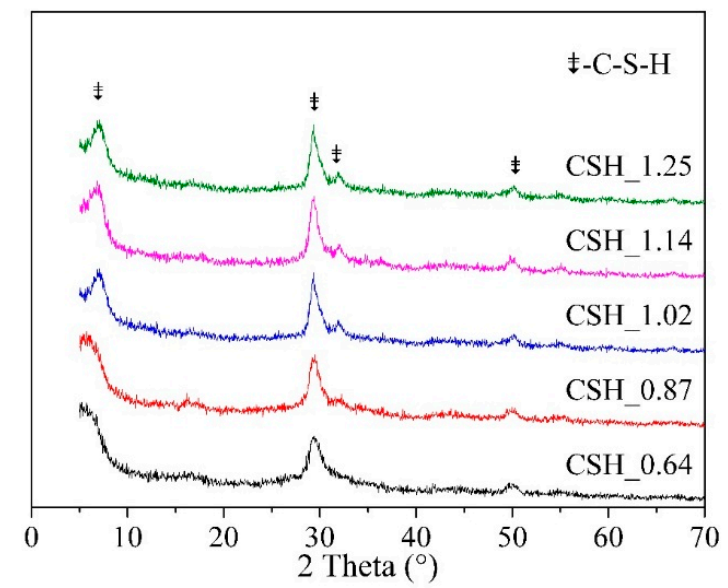

(a)

Figure 1. Cont. 


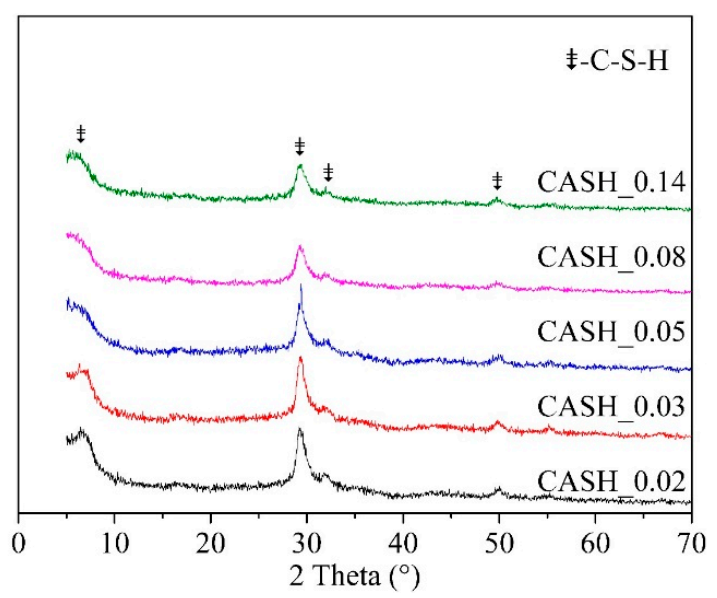

(b)

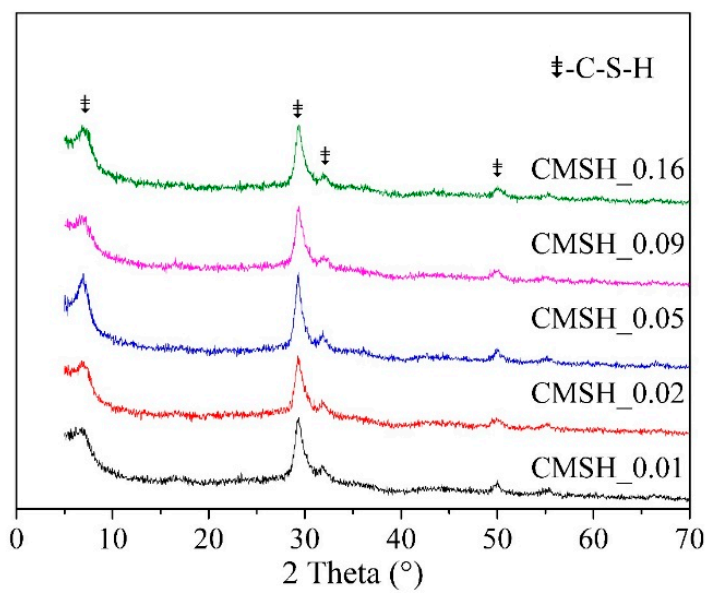

(c)

Figure 1. X-ray diffraction (XRD) analysis of synthesized C-(M)-(A)-S-H: (a) Ca/Si; (b) Al/Si; (c) Mg/Si.

The effect of $\mathrm{Ca} / \mathrm{Si}$ ratio on the structure of C-S-H were analyzed by comparing samples CSH_0.64, CSH_0.87, CSH_1.02, CSH_1.14 and CSH_1.25 (see Figure 1a). As the Ca/Si ratio increased, the $2 \theta$ value of the small angle diffraction peak (002) increased, which means the distance of the interlayer decreased from about $14 \AA$ to $13 \AA$. The interlayer distance decreased as the increase of $\mathrm{Ca} / \mathrm{Si}$ ratio, which was corresponding to the empty bridging silica tetrahedron. The effect of $\mathrm{Al} / \mathrm{Si}$ ratio on the structure of C-S-H were analyzed by comparing samples CSH_1.02, CASH_0.01, CASH_0.025, CASH_0.05 CASH_0.1 and CASH_0.2 (see Figure 1b). Although they had similar Ca/Si ratios, the $2 \theta$ value of small angle diffraction peak of sample C-A-S-H shifted to low angle, indicating that the basal spacing in $\mathrm{C}-\mathrm{A}-\mathrm{S}-\mathrm{H}$ was larger than that in C-S-H. It may be because the aluminum entered the structure of C-S-H by substituting silicium that linked across interlayer, which increased the distance of the interlayer. The effect of $\mathrm{Mg} / \mathrm{Si}$ ratio on the structure of C-S-H were analyzed by comparing samples CSH_1.0, CMSH_0.01, CMSH_0.025, CMSH_0.05 CMSH_0.1 and CMSH_0.2 (see Figure 1c). The presence of magnesium may improve the long-range order of the C-S-H structure, which is known from the increment of diffraction peak intensity. But the d-value of C-M-S-H had no obvious change compared with C-S-H with a same $\mathrm{Ca} / \mathrm{Si}$ ratio.

To further characterize the structure of C-S-H, parts of samples were then analyzed by using NMR. Figure 2 shows the ${ }^{29} \mathrm{Si} \mathrm{NMR}$ results of synthesized samples. The $\mathrm{Ca} / \mathrm{Si}$ ratio, $\mathrm{Al} / \mathrm{Si}$ ratio and $\mathrm{Mg} / \mathrm{Si}$ ratio of C-(M)-(A)-S-H had a direct influence on the structure of C-(M)-(A)-S-H. Table 2 gives the corresponding frequencies, band assignments, relative content of $\mathrm{Q}^{\mathrm{n}}$, and silicate chain length. 
The main characteristic peaks appeared at around $79 \mathrm{ppm}\left(\mathrm{Q}^{1}\right), 83 \mathrm{ppm}\left(\mathrm{Q}^{2} \mathrm{~b}\right.$, bridging position), $85 \mathrm{ppm}\left(\mathrm{Q}^{2} \mathrm{p}\right.$, pairing position), $88 \mathrm{ppm}\left(\mathrm{Q}^{2} \mathrm{u}\right.$, bridging position), $95 \mathrm{~cm}^{-1}\left(\mathrm{Q}^{3}\right)$, which were typical bands of C-S-H.

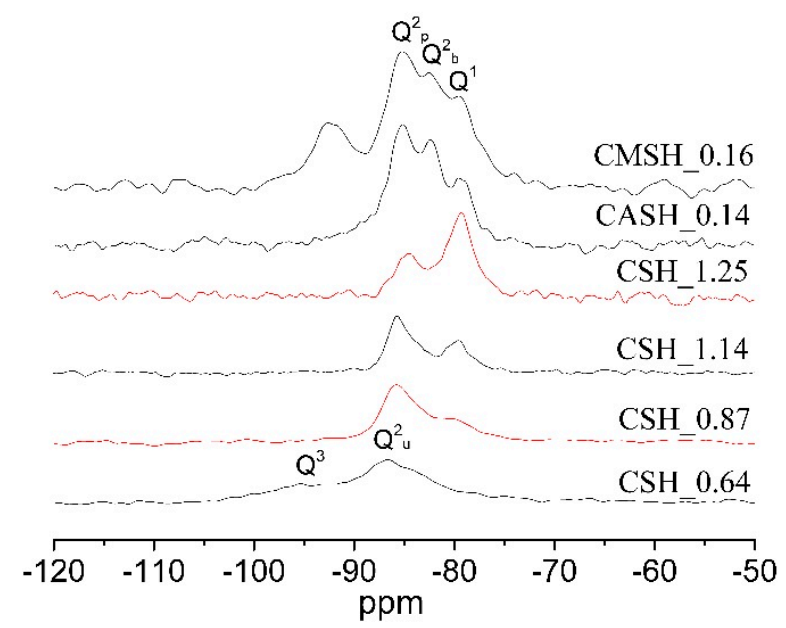

Figure 2. Nuclear magnetic resonance (NMR) spectra of C-(M)-(A)-S-H before carbonation.

Table 2. Peak shifts, relative fraction of $\mathrm{Q}^{\mathrm{n}}$, and mean chain length of $\mathrm{C}-(\mathrm{M})-(\mathrm{A})-\mathrm{S}-\mathrm{H}$ samples.

\begin{tabular}{|c|c|c|c|c|c|c|c|c|c|c|c|}
\hline \multirow{2}{*}{ Samples } & \multicolumn{2}{|c|}{$\mathrm{Q}^{1}$} & \multicolumn{2}{|c|}{$Q^{2} p$} & \multicolumn{2}{|c|}{$\mathrm{Q}^{2}{ }_{\mathrm{b}}$} & \multicolumn{2}{|c|}{$Q^{2} u$} & \multicolumn{2}{|c|}{$Q^{3}$} & \multirow{2}{*}{ CL } \\
\hline & ppm & $\%$ & ppm & $\%$ & ppm & $\%$ & ppm & $\%$ & ppm & $\%$ & \\
\hline CSH_0.64 & 79.00 & 9.37 & 84.17 & 23.16 & 91.46 & 9.76 & 87.00 & 36.27 & 95.35 & 21.44 & 16.77 \\
\hline CSH_0.87 & 79.48 & 24.92 & 85.75 & 59329 & 83.57 & 15.80 & / & I & / & / & 8.03 \\
\hline CSH_1.14 & 79.71 & 33.47 & 85.62 & 41.75 & 83.77 & 24.78 & / & / & / & / & 5.97 \\
\hline CSH_1.25 & 79.34 & 64.37 & 84.54 & 35.63 & / & / & / & / & / & l & 3.11 \\
\hline CASH_0.14 & 79.38 & 19.53 & 85.30 & 44.96 & 82.40 & 30.03 & 88.48 & 4.28 & 91.60 & 1.20 & 10.12 \\
\hline CMSH_0.16 & 79.57 & 20.49 & 85.43 & 37.08 & 82.47 & 22.31 & / & / & 92.20 & 20.08 & 7.80 \\
\hline
\end{tabular}

The high content of the Si-O band in the $\mathrm{Q}^{1}$ site represented the lower polymerization degree and short silicate chain, and vice versa. As shown in Table 2, the mean chain length of C-S-H increased from 3.11 to 16.77 as the Ca/Si ratio decreased from 1.25 to 0.64 , which means C-S-H with a low Ca/Si ratio has a higher degree of polymerization of silicon chain. Moreover, at low Ca/Si ratio (i.e., CSH_0.64), $\mathrm{Si}-\mathrm{O}$ band in $\mathrm{Q}^{3}$ site existed in pure C-S-H. The content of silicate tetrahedron in bridging the position increased when aluminum was added, indicating that part of aluminum enters the structure of C-S-H by replacing the bridge silicium. ${ }^{29} \mathrm{Si}$ NMR results also showed that cross-linked silicate groups $\left(\mathrm{Q}^{3}\right)$ existed in sample CMSH_0.16. Reference [40] believed that the $\mathrm{Q}^{3}$ site in C-(M)-S-H was the signal for the formation of M-S-H.

\subsection{The Effect of Time on the Evolution of Carbonation Products of C-S-H with Different Ca/Si Ratio}

\subsubsection{Carbonation Products}

Figure 3 gives the XRD patterns of samples after carbonation for 1day, 7 days and 28 days. Generally speaking, the carbonation products were calcite and vaterite with the same chemical formula expressed as $\mathrm{CaCO}_{3}$. The intensity of the diffraction peaks of the carbonation products became stronger as the carbonation time prolonged, indicating the carbonation degree of C-S-H became higher. But the type of carbonation product remain unchanged. At the same carbonation time, C-S-H with a low $\mathrm{Ca} / \mathrm{Si}$ ratio may have a better carbonation resistance by comparing the intensity of diffraction peaks of $\mathrm{CaCO}_{3}$. Besides, in sample CSH_1.02, the formation of calcite was earlier than the formation of vaterite. Therefore, vaterite might not be the transition phase of calcite. 


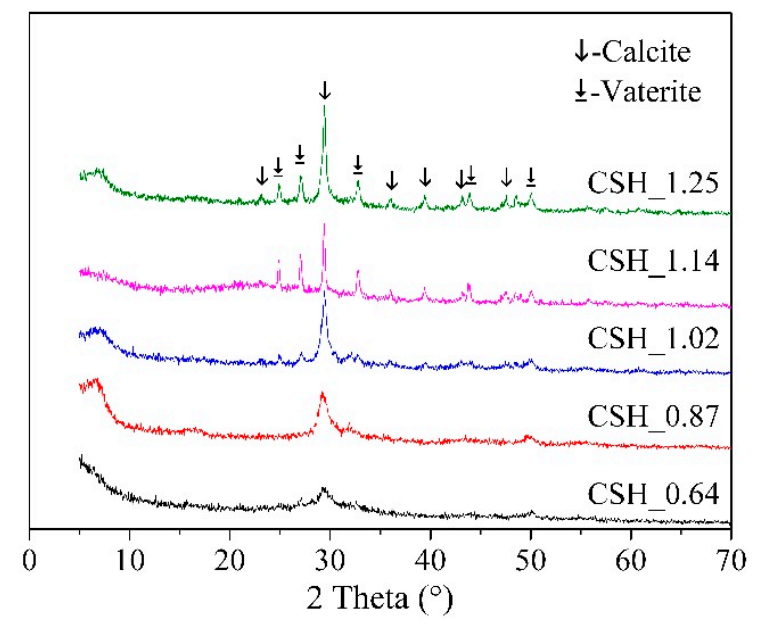

(a)

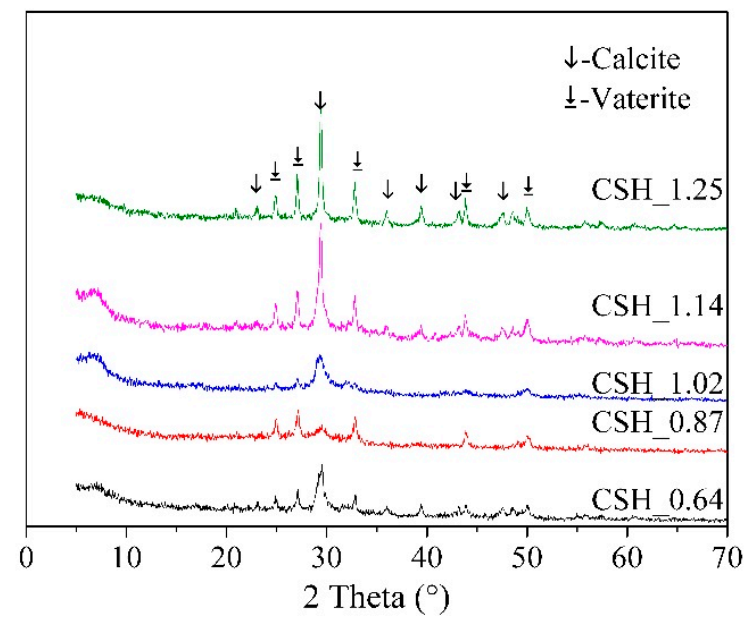

(b)

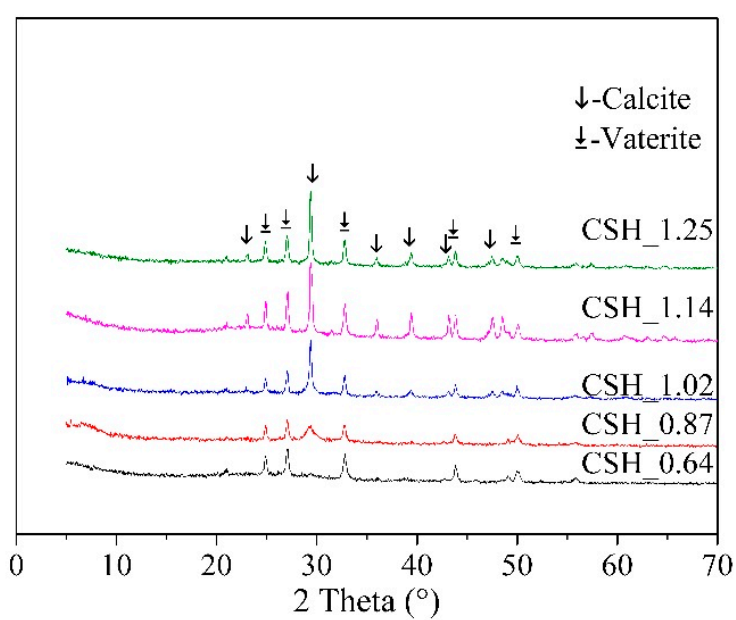

(c)

Figure 3. XRD patterns of C-S-H with different $\mathrm{Ca} / \mathrm{Si}$ ratio after carbonation for (a) 1 day, (b) 7 days and (c) 28 days. 
The $\mathrm{Ca} / \mathrm{Si}$ ratio of C-S-H had a crucial influence on the type of carbonation products. When the $\mathrm{Ca} / \mathrm{Si}$ ratio of $\mathrm{C}-\mathrm{S}-\mathrm{H}$ was lower than 0.87 , i.e., $\mathrm{CSH} \_0.87$, the carbonation product was vaterite. When the $\mathrm{Ca} / \mathrm{Si}$ ratio was higher than 1.02, i.e., $\mathrm{CSH} \_1.02$, both vaterite and calcite appeared as carbonation products. It is suggest that $\mathrm{C}-\mathrm{S}-\mathrm{H}$ with low $\mathrm{Ca} / \mathrm{Si}$ ratio have a calcium octahedral sheets structure, similar symmetries, and a positive charge of the gel surface to vaterite [37]. As for the C-S-H with high $\mathrm{Ca} / \mathrm{Si}$ ratio, both vaterite and calcite (negative surface charge) are generated at the same time. It implies that Ca-rich C-S-H may include two kinds of structure: one was similar to vaterite, the other was similar to calcite. Therefore, both vaterite and calcite appeared when C-S-H with high $\mathrm{Ca} / \mathrm{Si}$ ratio carbonated. However, Black et al. believed that vaterite was the main crystal structure as the $\mathrm{Ca} / \mathrm{Si}$ ration ranged from 0.67 to 1.5 [37]. This result was inconsistent with our experimental result where we demonstrated that the crystal structure of $\mathrm{CaCO}_{3}$ varies with the $\mathrm{Ca} / \mathrm{Si}$ ratio of C-S-H.

\subsubsection{The Effect of $\mathrm{Ca} / \mathrm{Si}$ Ratio of C-S-H on the Formation Rate of Carbonation Products}

The content of $\mathrm{CaCO}_{3}$ was determined by means of TGA. Figure $4 a, b$ show the TGA patterns of synthesized C-S-H before and after carbonation for 28 days, respectively. The corresponding data of $\mathrm{CaCO}_{3}$ content is given in Table 3. The value of CCP corresponding to the content of carbonation products of C-S-H. A small value of CCP represented the low carbonation degree and the strong carbonation resistance of C-S-H.

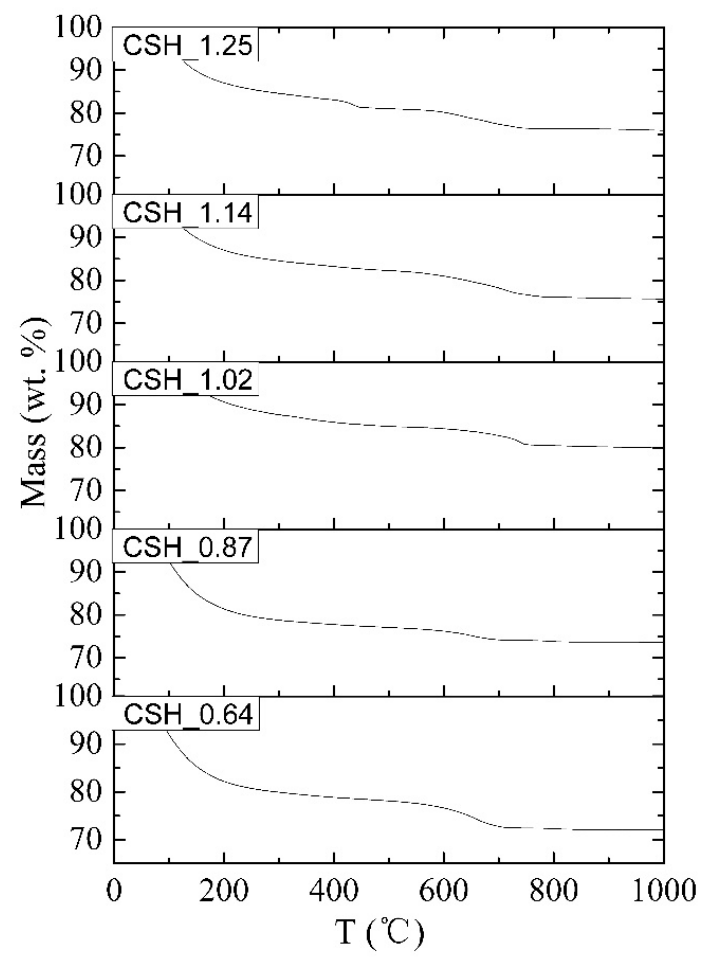

(a)

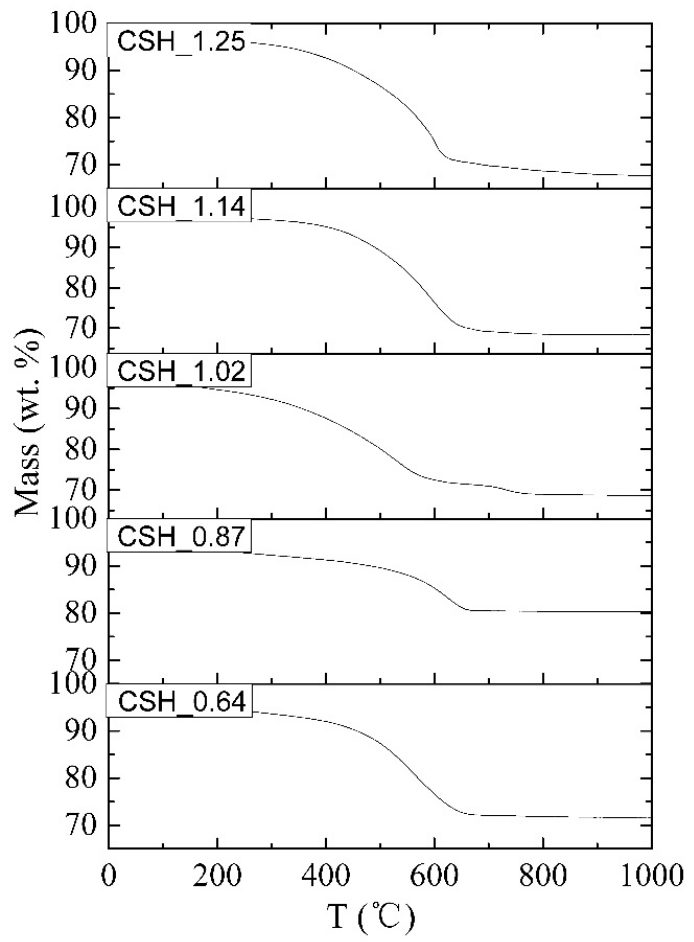

(b)

Figure 4. TGA patterns of C-S-H (a) before carbonation and (b) after carbonation for 28 days.

According to the results of Figure 4 and Table 3, it is clear that, for all the samples, the content of $\mathrm{CO}_{2}$ increased as the carbonation time prolonged. The CCP of C-S-H initially decreased and then increased with the increasing Ca/Si ratio. Sample CSH_0.87 had the smallest value of CCP (6.43), while sample CSH_1.25 had the biggest value of CCP (14.85). The order of carbonation resistance of C-S-H with different Ca/Si ratio was as follows: CSH_0.87 (6.43) > CSH_1.02 (8.70) > CSH_0.64 (13.21) $>$ CSH_1.14 (14.02) > CSH_1.25 (14.85). C-S-H with Ca/Si ratio around 0.9 had a better carbonation resistance which agreed well with the XRD results (Figure 3) and other researchers' results $[37,41]$. 
The CL of C-S-H increased as the decreasing of Ca/Si ratio (Figure 2 and Table 2), implying higher polymerization degree, higher bond strength and shorter bond length. Decalcification of such C-S-H is more difficult because the acting force of ( $\mathrm{Si}-\mathrm{O})$ to $\mathrm{Ca}$ is stronger. This may be the reason why C-S-H with a low $\mathrm{Ca} / \mathrm{Si}$ ratio has a better carbonation resistant than the one with a high $\mathrm{Ca} / \mathrm{Si}$ ratio (Figure 4).

Table 3. The content of $\mathrm{CO}_{2}$ of $\mathrm{C}-\mathrm{S}-\mathrm{H}$ before and after carbonation by mean of thermogravimetric analyzer (TGA).

\begin{tabular}{|c|c|c|c|c|c|}
\hline \multirow{2}{*}{ Samples } & \multicolumn{4}{|c|}{ Mass Loss (wt. \%) from TGA Data ${ }^{c}$} & \multirow{2}{*}{$C C P^{b}$} \\
\hline & $\mathrm{CO}_{2} \mathrm{O}^{\mathrm{a}}$ & $\mathrm{CO}_{2-1} 1$ & $\mathrm{CO}_{2-} 7$ & $\mathrm{CO}_{2} 28$ & \\
\hline CSH_0.64 & 2.72 & 4.5 & 12.37 & 15.93 & 13.21 \\
\hline CSH_0.87 & 2.69 & 2.97 & 5.53 & 9.12 & 6.43 \\
\hline CSH_1.02 & 3.87 & 4.36 & 5.69 & 12.57 & 8.70 \\
\hline CSH_1.14 & 6.31 & 9.30 & 10.60 & 20.33 & 14.02 \\
\hline CSH_1.25 & 4.71 & 15.95 & 20.94 & 19.56 & 14.85 \\
\hline
\end{tabular}

${ }^{a} \mathrm{CO}_{2} \mathrm{~N}$ : the content of $\mathrm{CO}_{2}$ after carbonation for $\mathrm{N}$ day, $\mathrm{N}$ is the carbonation time. ${ }^{\mathrm{b}} \mathrm{CCP}$ : the content of carbonation products $=\mathrm{CO}_{2} 28-\mathrm{CO}_{2}-0 .{ }^{\mathrm{c}}$ TGA patterns of $\mathrm{C}-\mathrm{S}-\mathrm{H}$ after carbonation for 1 day and 7 days have not presented in this paper, only TGA data listed in Table 3.

\subsubsection{The Structure Change of C-S-H with Different Ca/Si Ratio after Carbonation for 28 Days}

Figure 5 shows the ${ }^{29}$ Si NMR spectra of C-S-H after carbonation for 28 days. Combined with the NMR results of C-S-H before carbonation (see Figure 2), it was clear that the intensity of Si-O band in $\mathrm{Q}^{1}$ and $\mathrm{Q}^{2}$ sites reduced distinctly. Moreover, some new signals were observed at around $-112 \mathrm{ppm}$, -100 ppm in Figure 5, which were assign to Si-O band in $\mathrm{Q}^{4}$ and $\mathrm{Q}^{3}$ sites. These results indicated that the frequency of Si-O band in C-S-H switched to lower frequency from $Q^{1}$ and $Q^{2}$ sites to $Q^{3}$ and $Q^{4}$ sites, which means the carbonation of C-S-H formed calcium carbonate and silica gel (or C-S-H with low $\mathrm{Ca} / \mathrm{Si}$ ratio).

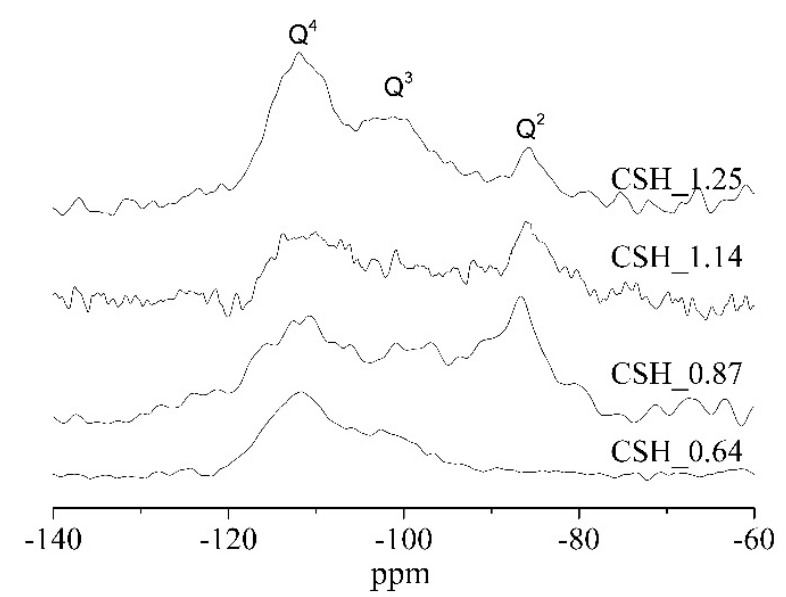

Figure 5. ${ }^{29} \mathrm{Si}$ NMR spectra of C-S-H after carbonation for 28 days.

3.3. The Effects of Aluminum Uptake and Magnesium Uptake in C-S-H on the Formation Rate of Carbonation Products after Carbonation for 28 Days

\subsubsection{The Effect of Aluminum}

The effect of Al/Si ratio on the carbonation behavior of C-(A)-S-H was studied by means of XRD and the Rietveld method. The XRD patterns of C-(A)-S-H after carbonation for 28 days are presented in Figure 6. According to Figure 6, the main carbonation products of C-(A)-S-H with Ca/Si ratio around 1.0 were vaterite and calcite. The diffraction peaks' intensity of calcite became stronger as the $\mathrm{Al} / \mathrm{Si}$ ratio decreases, indicating the aluminum uptake in C-S-H may hinder to the formation of calcite during 
the carbonation process. The calculated data of the content of carbonation product is listed in Table 4 . It is obvious that the content of calcite was reduced from $13.88 \mathrm{wt}$. \% to $2.77 \mathrm{wt}$. \% as the $\mathrm{Al} / \mathrm{Si}$ ratio increased. Figure 7 presents the relationship between $\mathrm{Al} / \mathrm{Si}$ ratio and total content of $\mathrm{CaCO}_{3}$. It was clear that no significant changes in the total content of $\mathrm{CaCO}_{3}$ as the $\mathrm{Al} / \mathrm{Si}$ ratio increased, indicating the carbonation resistance of C-S-H was not affected by the aluminum uptake in C-S-H obviously.

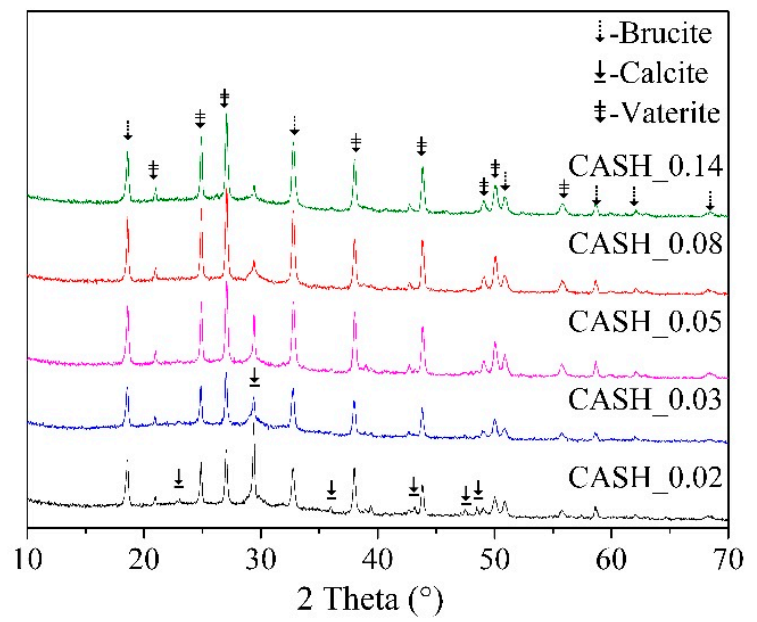

Figure 6. XRD analysis of C-(A)-S-H after carbonation for 28 days.

Table 4. The effect of $\mathrm{Al} / \mathrm{Si}$ ratio on the content of calcite and vaterite.

\begin{tabular}{ccccc}
\hline Samples & Calcite & Vaterite & Total CaCO $_{3}$ & Amorphous Phase \\
\hline CASH_0.02 & 13.88 & 33.36 & 47.24 & 52.76 \\
CASH_0.03 & 4.90 & 37.79 & 42.69 & 57.31 \\
CASH_0.05 & 6.92 & 39.31 & 46.22 & 53.78 \\
CASH_0.08 & 4.18 & 43.21 & 47.39 & 52.61 \\
CASH_0.14 & 2.77 & 44.25 & 47.03 & 52.97 \\
\hline
\end{tabular}

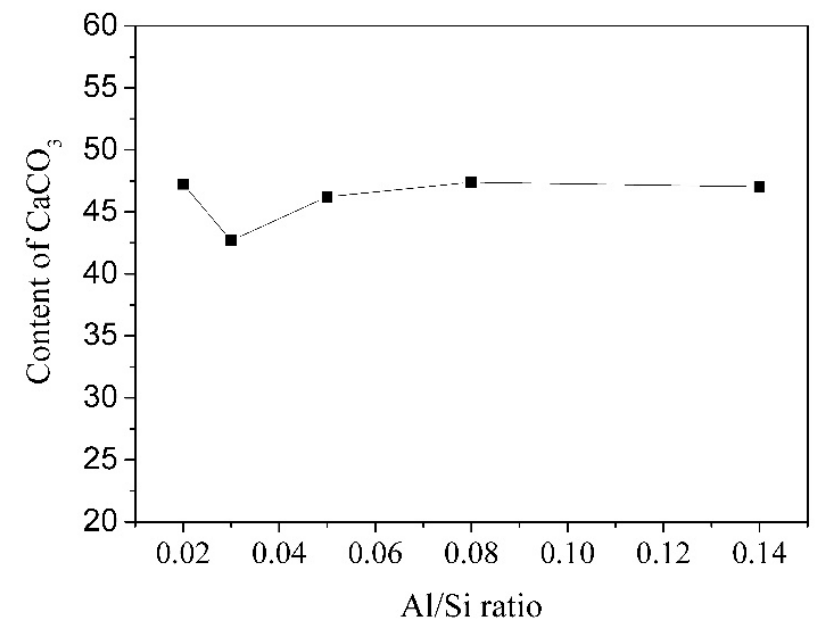

Figure 7. The effect of $\mathrm{Al} / \mathrm{Si}$ ratio on the content of $\mathrm{CaCO}_{3}$.

According to Table 2 and Figure 2, the content of $\mathrm{Q}^{2}$ in bridging site increased when $\mathrm{Al}$ enters the structure of C-S-H, which means C-A-S-H had more polymerized units and stronger bond strength. However, the entrance of aluminum into C-S-H also enlarged the interlayer distance, which increased the porosity of the gel. Therefore, the carbonation resistance of C-S-H has not improved obviously when aluminum entered the structure of C-S-H. 


\subsubsection{The Effect of Magnesium}

The effect $\mathrm{Mg} / \mathrm{Si}$ ratio on the carbonation behavior of $\mathrm{C}-(\mathrm{M})-\mathrm{S}-\mathrm{H}$ after carbonation for 28 days was also studied by using XRD, as shown in Figure 8. The main carbonation products of C-(M)-S-H were also calcite and vaterite. Unlike Figure 6, the diffraction peak intensity of vaterite became weaker as the $\mathrm{Mg} / \mathrm{Si}$ ratio increased, indicating the magnesium uptake in C-S-H may hinder the formation of vaterite. The content of calcite and vaterite of carbonated C-(M)-S-H is listed in Table 5. When the $\mathrm{Mg} / \mathrm{Si}$ ratio increased from 0.01 to 0.16 , the content of vaterite decreased from $32.86 \mathrm{wt}$. \% to $1.17 \mathrm{wt}$. $\%$, while the content of calcite had no obviously change. Figure 9 gives the variation of total content of $\mathrm{CaCO}_{3}$ as a function of the $\mathrm{Mg} / \mathrm{Si}$ ratio of C-(M)-S-H. The total content of $\mathrm{CaCO}_{3}$ reduced from 49.94 wt. \% to $21.22 \mathrm{wt}$. \% with increasing $\mathrm{Mg} / \mathrm{Si}$ ratio. The results implied that the magnesium uptake in C-S-H could improve its carbonation resistance, especially when the $\mathrm{Mg} / \mathrm{Si}$ ratio was bigger than 0.08 .

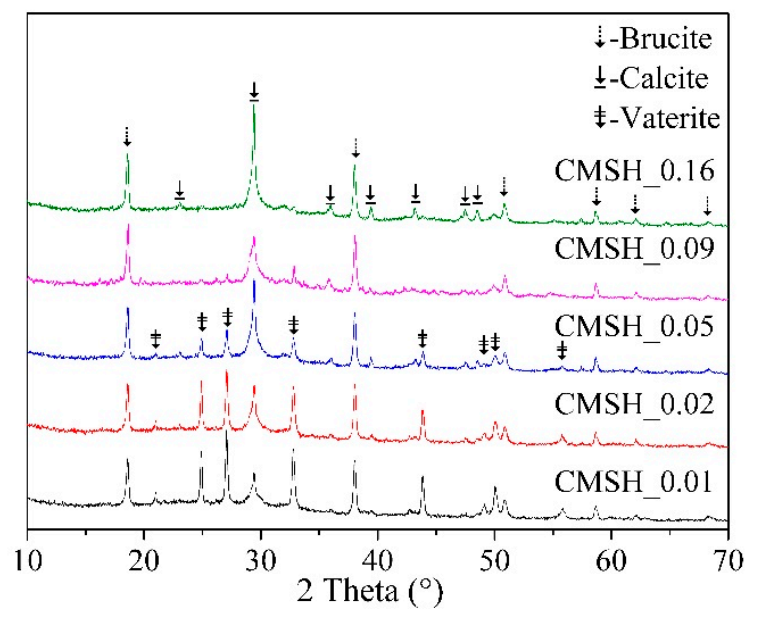

Figure 8. XRD analysis of C-(M)-S-H after carbonation for 28 days.

Table 5. The effect of $\mathrm{Al} / \mathrm{Si}$ ratio on the content of calcite and vaterite.

\begin{tabular}{ccccc}
\hline Samples & Calcite & Vaterite & Total $\mathrm{CaCO}_{3}$ & Other Phase \\
\hline CMSH_0.01 & 17.08 & 32.86 & 49.94 & 50.06 \\
CMSH_0.02 & 15.19 & 33.37 & 48.56 & 51.44 \\
CMSH_0.05 & 20.37 & 19.98 & 40.35 & 59.65 \\
CMSH_0.09 & 16.45 & 2.45 & 18.90 & 81.10 \\
CMSH_0.16 & 20.05 & 1.17 & 21.22 & 78.78 \\
\hline
\end{tabular}

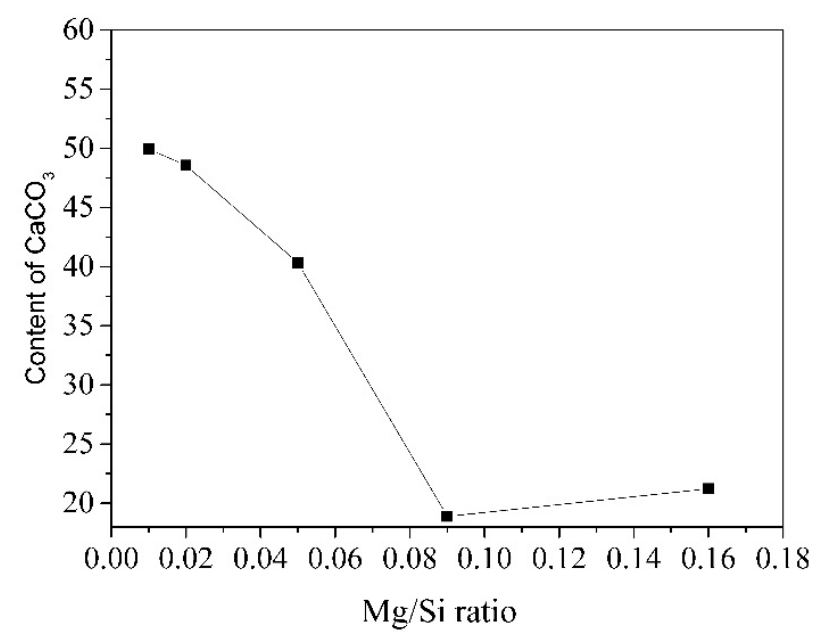

Figure 9. The effect of $\mathrm{Mg} / \mathrm{Si}$ ratio on the content of $\mathrm{CaCO}_{3}$. 
According to Table 2 and Figure 2, a cross-linked structure appeared $\left(\mathrm{Q}^{3}\right)$ when the magnesium uptake in C-S-H occurred, indicating a higher degree of polymerization of silicon chain. Besides, reference [40] believed that the appearance of $\mathrm{Q}^{3}$ is the signal of the formation of M-S-H with a clay-like structure, therefore the mixture of C-S-H and M-S-H may be more compact. Both of these two reasons can make the C-(M)-S-H have a better carbonation resistance than C-S-H.

\section{Conclusions}

The effects of $\mathrm{Ca} / \mathrm{Si}$ ratio, $\mathrm{Al} / \mathrm{Si}$ ratio and $\mathrm{Mg} / \mathrm{Si}$ ratio on the structure and carbonation behavior of C-(M)-(A)-S-H were investigated by means of XRD, NMR and TGA. The results showed that the polymerization degree of silicon chain decreased as the $\mathrm{Ca} / \mathrm{Si}$ ratio of $\mathrm{C}-\mathrm{S}-\mathrm{H}$ increased, which means $\mathrm{C}-\mathrm{S}-\mathrm{H}$ with a low $\mathrm{Ca} / \mathrm{Si}$ ratio had a higher bond strength and shorter bond length. The content of the Si-O band in bridging site $\left(\mathrm{Q}^{2}\right)$ increased obviously with aluminum uptake in C-S-H, indicating long silicate chains and large interlayer distance. An obvious peak of band Si-O in $\mathrm{Q}^{3}$ site appeared with magnesium uptake in C-S-H before carbonation, which was a signal of the formation of M-S-H. Generally speaking, the length of silicate chains in C-(M)-(A)-S-H increased as the $\mathrm{Ca} / \mathrm{Si}$ ratio decreased and $\mathrm{Al} / \mathrm{Si}$ ratio and $\mathrm{Mg} / \mathrm{Si}$ ratio increased.

Due to the differences in the structure of C-S-H, the carbonation products and carbonation resistance were various. For the samples with different $\mathrm{Ca} / \mathrm{Si}$ ratio, the main carbonation product was vaterite, if the $\mathrm{Ca} / \mathrm{Si}$ ratio was lower than 0.87 . When the $\mathrm{Ca} / \mathrm{Si}$ ratio was bigger than 1.02 , the main products were vaterite and calcite. The $\mathrm{C}-\mathrm{S}-\mathrm{H}$ with a low $\mathrm{Ca} / \mathrm{Si}$ ratio had a better carbonation resistance. For the samples with a different $\mathrm{Al} / \mathrm{Si}$ ratio, the carbonation resistance of $\mathrm{C}-(\mathrm{A})-\mathrm{S}-\mathrm{H}$ did not change visibly as the $\mathrm{Al} / \mathrm{Si}$ ratio increased. Moreover, the content of calcite decreased as the $\mathrm{Al} / \mathrm{Si}$ ratio increased. For the samples with different $\mathrm{Mg} / \mathrm{Si}$ ratio, the carbonation resistance of C-(M)-S-H improved obviously, especially when the $\mathrm{Mg} / \mathrm{Si}$ ratio was bigger than 0.08 . Moreover, the content of vaterite decreased as the $\mathrm{Al} / \mathrm{Si}$ ratio increased. In general, $\mathrm{C}-(\mathrm{M})-\mathrm{S}-\mathrm{H}$ (total $\mathrm{CaCO}_{3}$ content of $\mathrm{CMSH} \_0.16$ after carbonation for 28 days: $21.22 \mathrm{wt}$. \%) has a better carbonation resistance than C-(A)-S-H (total $\mathrm{CaCO}_{3}$ content of CASH_0.16 after carbonation for 28 days: 47.03 wt. \%).

Author Contributions: Conceptualization, Q.Y. and S.Y.; Methodology, J.L.; Software, J.L.; Validation, Q.Y., S.Y. and H.H.; Formal Analysis, J.L.; Investigation, J.L.; Resources, Q.Y. and S.Y.; Data Curation, J.L.; Writing-Original Draft Preparation, J.L.; Writing-Review \& Editing, H.H.; Visualization, J.L. and H.H.; Supervision, Q.Y.; Project Administration, S.Y.; Funding Acquisition, S.Y.

Funding: This research was funded by National Natural Science Foundation of China with grant number of 51561135012 and Open Fund of State Key Laboratory of High Performance Civil Engineering Materials with grant number of 2015CEM002. The APC was funded by National Natural Science Foundation of China (51561135012).

Acknowledgments: The authors gratefully acknowledge the financial support of National Natural Science Foundation of China (51561135012) and Open Fund of State Key Laboratory of High Performance Civil Engineering Materials (2015CEM002).

Conflicts of Interest: The authors declare no conflict of interest.

\section{References}

1. Wang, S.; Peng, X.; Tang, L.; Cao, C.; Zeng, L. Contact-Hardening Behavior of Calcium Silicate Hydrate Powders. Materials 2018, 11, 2367. [CrossRef] [PubMed]

2. Hung, C.-C.; Wu, Y.-C.; Lin, W.-T.; Chang, J.-J.; Yeih, W.-C. Effect of Mixture Variables on Durability for Alkali-Activated Slag Cementitious. Materials 2018, 11, 2252. [CrossRef]

3. Song, K.-I.; Song, J.-K.; Lee, B.Y.; Yang, K.-H. Carbonation Characteristics of Alkali-Activated Blast-Furnace Slag Mortar. Adv. Mater. Sci. Eng. 2014, 2014, 1-11. [CrossRef]

4. Li, N.; Farzadnia, N.; Shi, C. Microstructural changes in alkali-activated slag mortars induced by accelerated carbonation. Cem. Concr. Res. 2017, 100, 214-226. [CrossRef]

5. Sevelsted, T.F.; Skibsted, J. Carbonation of C-S-H and C-A-S-H samples studied by 13C, 27Al and 29Si MAS NMR spectroscopy. Cem. Concr. Res. 2015, 71, 56-65. [CrossRef] 
6. Borges, P.H.; Costa, J.O.; Milestone, N.B.; Lynsdale, C.J.; Streatfield, R.E. Carbonation of CH and C-S-H in composite cement pastes containing high amounts of BFS. Cem. Concr. Res. 2010, 40, 284-292. [CrossRef]

7. Bakharev, T.; Sanjayan, J.G.; Cheng, Y.B. Resistance of alkali-activated slag concrete to carbonation. Cem. Concr. Res. 2001, 31, 1277-1283. [CrossRef]

8. Gong, K.; White, C.E. Impact of chemical variability of ground granulated blast-furnace slag on the phase formation in alkali-activated slag pastes. Cem. Concr. Res. 2016, 89, 310-319. [CrossRef]

9. Kamali, M.; Ghahremaninezhad, A. A Study of Calcium-Silicate-Hydrate/Polymer Nanocomposites Fabricated Using the Layer-By-Layer Method. Materials 2018, 11, 527. [CrossRef] [PubMed]

10. Bernard, E.; Lothenbach, B.; Cau-Dit-Coumes, C.; Chlique, C.; Dauzères, A.; Pochard, I. Magnesium and calcium silicate hydrates, Part I: Investigation of the possible magnesium incorporation in calcium silicate hydrate (CSH) and of the calcium in magnesium silicate hydrate (MSH). Appl. Geochem. 2018, 89, 229-242. [CrossRef]

11. Battocchio, F.; Monteiro, P.J.M.; Wenk, H.R. Rietveld refinement of the structures of $1.0 \mathrm{CSH}$ and $1.5 \mathrm{CSH}$. Cem. Concr. Res. 2012, 42, 1534-1548. [CrossRef]

12. Lodeiro, I.G.; Macphee, D.E.; Palomo, A.; Fernández-Jiménez, A. Effect of alkalis on fresh C-S-H gels. FTIR analysis. Cem. Concr. Res. 2009, 39, 147-153. [CrossRef]

13. Renaudin, G.; Russias, J.; Leroux, F.; Frizon, F.; Cau-dit-Coumes, C. Structural characterization of C-S-H and C-A-S-H samples—part I: Long-range order investigated by Rietveld analyses. J. Solid State Chem. 2009, 182, 3312-3319. [CrossRef]

14. Chen, W.; Brouwers, H.J.H. The hydration of slag, part 1: Reaction models for alkali-activated slag. J. Mater. Sci. 2007, 42, 428-443. [CrossRef]

15. Myers, R.J.; Bernal, S.A.; San Nicolas, R.; Provis, J.L. Generalized structural description of calcium-sodium aluminosilicate hydrate gels: The cross-linked substituted tobermorite model. Langmuir 2013, 29, 5294-5306. [CrossRef]

16. Richardson, I.G. Tobermorite/jennite-and tobermorite/calcium hydroxide-based models for the structure of CSH: Applicability to hardened pastes of tricalcium silicate, $\beta$-dicalcium silicate, Portland cement, and blends of Portland cement with blast-furnace slag, metakaolin, or silica fume. Cem. Concr. Res. 2004, 34, 1733-1777.

17. Richardson, I.G. Model structures for C-(A)-S-H (I). Acta Crystallograph. Sec. B Struct. Sci. Cryst. Eng. Mater. 2014, 70, 903-923. [CrossRef]

18. Myers, R.J.; Bernal, S.A.; Provis, J.L. A thermodynamic model for C-(N-) A-S-H gel: CNASH_ss. Derivation and validation. Cem. Concr. Res. 2014, 66, 27-47. [CrossRef]

19. Sun, G.K.; Young, J.F.; Kirkpatrick, R.J. The role of Al in C-S-H: NMR, XRD, and compositional results for precipitated samples. Cem. Concr. Res. 2006, 36, 18-29. [CrossRef]

20. Pegado, L.; Labbez, C.; Churakov, S.V. Mechanism of aluminium incorporation into C-S-H from ab initio calculations. J. Mater. Chem. 2014, 2, 3477-3483. [CrossRef]

21. Lognot, I.; Klur, I.; Nonat, A. NMR and Infrared Spectroscopies of CSH and Al-Substituted CSH Synthesised in Alkaline Solutions//Nuclear Magnetic Resonance Spectroscopy of Cement-Based Materials; Springer: Berlin/Heidelberg, Germany, 1998; pp. 189-196.

22. Colombet, P.; Grimmer, A.R.; Zanni, H.; Sozzani, P. Nuclear Magnetic Resonance Spectroscopy of Cement-Based Materials; Springer Science \& Business Media: Berlin, Germany, 2012.

23. Andersen, M.D.; Jakobsen, H.J.; Skibsted, J. A new aluminium-hydrate species in hydrated Portland cements characterized by 27Al and 29Si MAS NMR spectroscopy. Cem. Concr. Res. 2006, 36, 3-17. [CrossRef]

24. Faucon, P.; Delagrave, A.; Richet, C.; Marchand, J.M.; Zanni, H. Aluminum Incorporation in Calcium Silicate Hydrates (C-S-H) Depending on Their Ca/Si Ratio. J. Phys. Chem. B 1999, 103, 7796-7802. [CrossRef]

25. Qian, G.; Xu, G.; Li, H.; Li, A. Mg-Xonotlite and its coexisting phases. Cem. Concr. Res. 1997, 27, 315-320. [CrossRef]

26. L'Hôpital, E.; Lothenbach, B.; Kulik, D.; Scrivener, K. Influence of calcium to silica ratio on aluminium uptake in calcium silicate hydrate. Cem. Concr. Res. 2016, 85, 111-121. [CrossRef]

27. Pytel, Z.; Małolepszy, J. DTA studies of phases synthesized in the system $\mathrm{CaO}-\mathrm{MgO}-\mathrm{SiO}_{2}-\mathrm{H}_{2} \mathrm{O}$. Silicat. Ind. 2000, 7-8, 81-85.

28. Komarneni, S.; Breval, E.; Roy, D.; Roy, R. Reactions of some calcium silicates with metal cations. Cem. Concr. Res. 1988, 18, 204-220. [CrossRef] 
29. Shrivastava, O.P.; Komarneni, S.; Breval, E. $\mathrm{Mg}^{2+}$ uptake by synthetic tobermorite and xonotlite. Cem. Concr. Res. 1991, 21, 83-90. [CrossRef]

30. Bernard, E.; Dauzères, A.; Lothenbach, B. Magnesium and calcium silicate hydrates, Part II: Mg-exchange at the interface "low-pH" cement and magnesium environment studied in a CSH and MSH model system. Appl. Geochem. 2018, 89, 210-218. [CrossRef]

31. Roosz, C.; Vieillard, P.; Blanc, P.; Gaboreau, S.; Gailhanou, H.; Braithwaite, D.; Montouillout, V.; Denoyel, R.; Henocq, P.; Madé, B. Thermodynamic properties of CSH, CASH and MSH phases: Results from direct measurements and predictive modelling. Appl. Geochem. 2018, 92, 140-156. [CrossRef]

32. Gruyaert, E.; Van den Heede, P.; De Belie, N. Carbonation of slag concrete: Effect of the cement replacement level and curing on the carbonation coefficient-Effect of carbonation on the pore structure. Cem. Concr. Compos. 2013, 35, 39-48. [CrossRef]

33. Mo, L.; Panesar, D.K. Accelerated carbonation-A potential approach to sequester $\mathrm{CO}_{2}$ in cement paste containing slag and reactive MgO. Cem. Concr. Compos. 2013, 43, 69-77. [CrossRef]

34. Kim, J.J.; Foley, E.M.; Taha, M.M.R. Nano-mechanical characterization of synthetic calcium-silicate-hydrate (C-S-H) with varying $\mathrm{CaO} / \mathrm{SiO}_{2}$ mixture ratios. Cem. Concr. Compos. 2013, 36, 65-70. [CrossRef]

35. Mendoza, O.; Giraldo, C.; Camargo, S.S., Jr.; Tobón, J.I. Structural and nano-mechanical properties of Calcium Silicate Hydrate (CSH) formed from alite hydration in the presence of sodium and potassium hydroxide. Cem. Concr. Res. 2015, 74, 88-94. [CrossRef]

36. Black, L.; Breen, C.; Yarwood, J.; Garbev, K.; Stemmermann, P.; Gasharova, B. Structural Features of C?S?H(I) and Its Carbonation in Air?A Raman Spectroscopic Study. Part II: Carbonated Phases. J. Am. Ceram. Soc. 2007, 90, 908-917. [CrossRef]

37. Garbev, K.; Stemmermann, P.; Black, L.; Breen, C.; Yarwood, J.; Gasharova, B. Structural features of C-S-H (I) and its carbonation in air-A Raman spectroscopic study. Part I: Fresh phases. J. Am. Ceram. Soc. 2007, 90, 900-907. [CrossRef]

38. Ashraf, W.; Olek, J. Carbonation activated binders from pure calcium silicates: Reaction kinetics and performance controlling factors. Cem. Concr. Compos. 2018, 93, 85-98. [CrossRef]

39. Li, X.-G.; Lv, Y.; Ma, B.-G.; Wang, W.-Q.; Jian, S.-W. Decomposition kinetic characteristics of calcium carbonate containing organic acids by TGA. Arab. J. Chem. 2017, 10, S2534-S2538. [CrossRef]

40. Bernard, E.; Lothenbach, B.; Le Goff, F.; Pochard, I.; Dauzères, A. Effect of magnesium on calcium silicate hydrate (C-S-H). Cem. Concr. Res. 2017, 97, 61-72. [CrossRef]

41. Black, L.; Garbev, K.; Gee, I. Surface carbonation of synthetic CSH samples: A comparison between fresh and aged CSH using X-ray photoelectron spectroscopy. Cem. Concr. Res. 2008, 38, 745-750. [CrossRef] 